\title{
Thesnaar, $\mathrm{CH}$ \\ Stellenbosch University
}

\section{Memories liberate the past}

\begin{abstract}
Memory is central in dealing with and being liberated from the trauma of the past. Individuals, families, communities and nations have struggled through the centuries to face and deal with their memories in a constructive way. Memory is thus indispensable for living in the present and hoping-for a reconciled future if people to reconcile with God, with those closest to them, with others and with themselves. This article argues that memory is a key element within the healing and reconciliation process for victims and perpetrators. To reach this goal the significance and content of memory need to be ascertained and understood.
\end{abstract}

\section{INTRODUCTION}

The focus of the Truth and Reconciliation Commission (TRC) was to assist South Africans, victims and perpetrators to deal with the trauma of the past by remembering it through storytelling. The narratives of those who had the privilege of appearing before the TRC were televised to motivate other victims and perpetrators not to hide their past in silence or to censor their narratives with the aim to protect the next generation. Although the TRC process tried their best to convey their message of remembrance to all South Africans, it faced some daunting challenges. Some of these challenges were that only about 20000 victims of a possible 44 million could share their narratives before the TRC and that very few perpetrators shared their narratives before the TRC. This was aggravated by how the mainly Afrikaans media motivated the perpetrators not to appeal for amnesty because the commission was portrayed as nothing more than a witch hunt. Added to this is the fact that the narration process lost its momentum virtually after the TRC process came to an end. This brought an end to the ideal of a nation remembering their past and dealing with it constructively in order to be liberated from it.

The German theologian Wolfgang Huber (1987:535) strongly supports the importance of dealing with the memories of the past when he acknowledges that freedom is not possible without memory. The challenging question we need to engage with is: How do we remember? Vosloo (2010:3) grappled with this question and conclude that we need a responsible historical hermeneutics that will enable us to deal with the struggles of the past. Ricoeur (2004:21) further accentuates time and again "that we have no other resource, concerning our reference to the past, except memory itself." Therefore the more we remember the past, listen to it and interpret it, the more freedom we will experience. Remembrance is thus essential for being liberated from our past, in order to live in the present with a new identity ${ }^{1}$ and to hope for a new future.

The goal of this article is to argue that memory is a key element within the healing and reconciliation process for victims and perpetrators. To reach this goal the significance and content of these decisive terms needs to be ascertained and understood. This article will begin by focusing on the psychological and Biblical-theological perspectives of memory ${ }^{2}$. This will be

1 See Schreiter (2004:74).

2 For other perspectives is on memory see Nwoye (2008:18) as he distinguishes between fact, behaviour, event and prospective memory. 
followed by highlighting the link between memory and identity and then stating that memory is about taking responsibility for the past. The article will conclude by emphasising the value of telling and sharing narratives in order to be liberated from the past.

\section{PSYCHOLOGICAL PERSPECTIVE OF MEMORY}

It is psychologically important for people to remember the functional memories from the past and to deal with the impact of dysfunctional memories in a constructive way ${ }^{3}$. According to Louw and Edwards (1998:285) it is normal to forget emotional painful traumatic memories. The term they use to explain this is: "motivated forgetting." According to them an extreme form of motivated forgetting is repression, i.e. the process through which the emotionally painful and distressing experiences are blocked from our memory. This forms a natural defence mechanism to people in dealing with traumatic memories of the past. People are often not aware that they are blocking out their emotional pain (Louw and Edwards, 1998:529), since it happens mostly in the subconscious mind. Alternately, they may choose consciously to privatise their pain by stating that their pain has nothing to do with others, and therefore they are not required to share it with anyone (Jordaan 2008:21). Although this sometimes helps people to deal with their immediate pain, it does not help in dealing with the extent and the effect of their pain in a constructive way. There could be numerous reasons why people tend to hide their pain from the past. Within the scope of this article it is helpful to identify some of these reasons:

- Memories and impulses that people keep in their subconscious do not necessarily disappear. They are generally still active in the life of the individual but normally-beyond his/her consciousness and control.

- Certain situations and other people can subconsciously activate this material. Therefore people try to avoid such stimuli, or they react in a very irrational ways when confronted with these memories.

- Defence mechanisms continue to cause people to lose vitality, or in less serious cases to feel vaguely dissatisfied with their life.

- It has been scientifically proved that when people do not deal with their pain or keep it to themselves, it will lead to chronic physical problems as well as to serious physical illnesses. Such people are also more inclined to suffer from anxiety and depression (Jordaan; et al, 2008:22).

Based on the above, this article wants to argue that traumatic thoughts, emotions and memories can cause pain to individuals, groups, communities and even nations ${ }^{4}$. These thoughts, emotions and memories from the past cannot just be stowed away without recognising that it can still have an effect on people in the present. Therefore psychologists emphasise the serious risk of hiding our traumatic past to the extent that they propose psychotherapy and hypnosis to assist people to deal with their traumatic pain from the past and to find healing from the pain (Louw and Edwards 1998:286).

This strong emphasis from the psychological perspective on remembering the past is intended to assist people to deal with their dysfunctional memories that haunt them in their present and future life. In terms of the effects of dysfunctional memory Holtschneider (2001:168) refers the emotional weight of the German past that is still evident in all three generations. In other words,

3 For an insightful explanation of the abuses of memory see the discussion by Ricoeur (2004:21) on: blocked memory (a psychological phenomenon caused by wounded memory), manipulated memory (instructed memory serving a specific cause or ideology), and abusively commanded memory (when people, very often children, recite official histories).

4 See Schreiter (2004:74). 
the dysfunctional memories of the German past still have a significant impact on the present and future life within Germany today. In this regard Blenkinsopp (1997:78) reminds us of the necessity to grieve about our past experiences in order to move on towards healing: "Grieving belongs with remembering as rejoicing with pleasure in the present moment or in the anticipation of pleasure in the near future. To grieve is to remember, to be unable to forget." Also within the South African context, grieving ${ }^{5}$ about the impact of the past experiences is fundamental for the perpetrator and the victim, in order to pave the way for the process of reconciliation and forgiveness. For this process to succeed, both the victim and the perpetrator need to take responsibility for their own past in order to move on and find meaning and wholeness within the present and in the future. It is about reconstructing the past in the present with the focus on the future. It is therefore essentially not the memory that needs to be restored, but the past that needs to be transformed within the present (Jordaan; et al., 2008:95).

Although this psychological perspective could be seen as humanistic due to its emphasis on the potential of the individual, group, community and nation for creating an improved and meaningful life and relations, it merits appreciation for its emphasis on the significance of memory for healing.

\section{BIBLICAL-THEOLOGICAL PERSPECTIVE OF MEMORY}

Memory has a deeply religious significance. According to Veldsman (in Jordaan et al., 2008:41) memory was born when time and space were created. This is already mentioned in the narrative of creation according to Genesis 2:4. and supported throughout the Bible as God continues to confirm that He will not forsake nor forget his people. This commitment is cemented within the covenant that forms the basis for the promise of salvation:

But Zion said, 'The Lord has forsaken me, the Lord has forgotten me.' Can a mother forget the baby at her breast and have no compassion on the child she has borne? Though she may forget, I will not forget you! (Isaiah: 49:14-15, N.J. translation) ${ }^{6}$

The covenantal promises of God and the emphasis on remembering these promises confirm that as believers we are part of a unique identity, which is explained by Olivera (1996:55) as follows: "The oral transmission of the Word of God, his commandments and his teachings not only entailed the use of memory, but also enabled God's people to know history and to preserve their identity and the relationship between each generation and its forebears." This is confirmed in Deuteronomy 4:9 (N.J. translation):

Only be careful, and watch yourselves closely so that you do not forget the things your eyes have seen or let them slip from your heart as long as you live. Teach them to your children and to their children after them.

For the believer the significance of identity is remembering the involvement of God in the lives of His people. This involvement confirms that He is never passive, for God's memory is always active and therefore resembles action. For example, God remembered Hanna, so that she eventually became pregnant (1 Sam.1:19) ${ }^{7}$. God is active within us via the covenantal promises. Therefore we constantly need to be reminded of the promises of God.

In the New Testament Jesus refers directly to the Eucharist when He says to the disciples:

"...do this in remembrance of Me." (Luke 22:19, N.J. translation)

By remembering the death and resurrection of Christ, the believers constantly ascertain their

5 For the importance of grieving in the African context, see Nwoye (2005:147).

6Also compare the following Bible verses in this regard: Exodus 17:14, Deuteronomy 4:23 \& 6:11-12 and

Psalm. 103:2.

7 See Isaiah 43:25, Psalm 23:4, Deuteronomy 9:27. 
identity as Christians. The memory is stimulated and focused in a powerful way by the use of the bread and the wine. This indicates that the more individuals and faith communities are exposed to the stories, rituals, moments and feasts of their past, the stronger it will confirm their identity in Christ. Although remembrance, as indicated in the Eucharist, is different than remembrance in terms of our memory, it does emphasise the importance of remembrance and memory.

The epistle to the Hebrews reprimands those who think about forgetting the suffering of the apostles. The author emphasises in Hebrews 10:32-34 that the congregation's own suffering, the battles they fought against injustices and the solidarity with those who suffered for the sake of their faith, should never be forgotten:

Remember those earlier days after you had received the light, when you stood your ground in a great contest in the face of suffering. Sometimes you were publicly exposed to insult and persecution; at other times you stood side by side with those who were so treated. You sympathised with those in prison and joyfully accepted the confiscation of your property, because you knew that you yourselves had better and lasting possessions (N.J. translation). The Bible constantly reminds us of the truth of the presence of God in our daily lives. This is illustrated by stories like the liberation from slavery and the rescue from enemies. The meaning of these stories is not to idealize the past but to indicate the new covenantal actions of God in the present and in the future. In this regard Gutiérrez (1979:12) affirms: "Biblical faith, however, besides being memory, is freedom: openness to the future. Recalling the liberating deeds of Yahweh is not the nostalgia of bygone days. All the great loves contains the memory of the first moment. In strong moments it is the fount of gladness, in difficult moments it is the reaffirmation of hope. In either case the gaze is to the fore. The future is the task. Memory thus has the function of conditioning a creative liberty." In terms of this the challenge for the believer is to remember the past, in order to be liberated from it, to live with meaning in the present and then to move to the future with intense expectation and hope.

The theological meaning of memory is enriched by the emphasis on remembrance of the cross and the resurrection of Christ within the New Testament. It also delineates the unique identity of believers, culminating in the great deeds of God on the cross and in the resurrection of Christ. God created a new humanity, woven together in Christ as a unique corpus where Christ Himself is present within their midst (Ephesians 2:13-22). In this regard He calls us to "remember ..." (Ephesians 2:11). Within this context Schreiter (2004:50) quotes Rowan Williams who masterfully describes that "God is the agency that gives us back our memories, because God is the 'presence' to which all reality is present." The remembrance of our traumatic past makes the transition to the present with our new identity in Christ just more exciting and joyful. It does not matter what crisis or trauma we have to face. God will not, abandon nor forget us, because He will accompany us as we enter our future - His future. His forgiveness and acquittal also entails that He forgets the sins of the people (Micah 7:18-20). Therefore forgetting within the Biblical text occurs only when God forgives sins.

Based on the argument thus far it is safe to indicate that remembrance within Scripture implies liberated and redemptive memory. This implies that it deals with life from death, light from darkness, good from evil and hope from despair. The liberated and redemptive memory is based on the covenant and actions of God with his people in the past, present and future; or in the words of Vosloo (2010:1), "the past, as the story of God's faithfulness, is time and again recalled as an identity-strengthening resource for life in the present". For Christians both the psychological and theological perspectives on memory emphasise the importance of dealing with the trauma of the past. 


\section{MEMORY GRANTS IDENTITY}

The German political theologian Johann Baptist Metz states in Faith in History and Society, that memory is indeed what give people, both as individuals and as communities, their historical identity: "Identity is formed when memories are aroused". When perpetrators and victims suppress the past and consciously strive to forget it, they build a destructive identity. This destructive identity can cause the stronger person, group or nation, to oppress the weaker person, group or nation, in order to find or maintain their identity. It is therefore possible that people with a lack of a sense of self-worth and identity, based on their selective memory, can justify almost everything to regain their identity, even if it entails oppressing others with violence or violating the rights of others.

The cycle of violence ${ }^{8}$ through which the culture of violence is passed from the one generation to the next can also easily incite xenophobia. In this sense violence is understood as any relation, process or condition by which and individual, group or nation violates the physical, social and/or psychological integrity of another person, group or nation. In this regard Santer (1998:129) confirms the effect of a destructive memory: "We abuse the gift of memory when we employ it for keeping ourselves in the right and others in the wrong, for keeping grievances alive and for perpetuating stereotypes which justify us in treating other groups in demeaning, or oppressive ways." This destructive identity can generate an evil cycle through which today's victims become tomorrow's perpetrators. To stop this cycle we need to understand the context of the victims and the perpetrators and be able to listen to their narratives in order to interpret it in a constructive way. This will enable us to challenge our identities constantly, and to prevent its escalation into a one-sided or destructive identity based on a selective memory. As indicated earlier, this is a real threat because negative memories might surface from the subconscious; by contrast, addressing the effect of negative memories on an emergent identity could well be the only cure for the person suffering as a result of shock in the past (Olivera, 1996:55).

Individuals, groups and nations construct an identity on the basis that victims tend to remember the pain caused by perpetrators, whilst perpetrators tend to forget the pain they have inflicted. According to Blenkinsopp (1997:76) "Scholars have often been observed that the collective consciousness of societies that have experienced disaster, the Irish and the Poles for example, is more profoundly shaped by memory than those whose experience of disaster is more episodic or, a fortiori, those who have acquired a reputation for inflicting disaster on others." The sad reality is that the effects of this conflict were passed on from the one generation to the next, and so resulted in the one suppressing the other. In this sense our identity is marked not only by what we, can remember as individuals, but by the corporate memories of the group or nation, and by what others that belong to the same group have informed us about our shared past (Santer, 1998:128). People are historical beings whose identity is embedded within their history, especially when it results from pain (Durand, 1993:292). Where generations are unable to apply a responsible historical hermeneutics to deconstruct the past they will simply inherit the memories of the previous generation.

Individuals, groups and nations should always be conscious of the fact that memory about the past can be very selective for victims and perpetrators alike. ${ }^{9}$ Santer (1998:128) uses the term "interpretation in the selective" to illustrate that people not only remember, but also interpret the past selectively. Memory is a selective and also a fluctuating process. Individuals, groups and nations communicate the essential happenings of the past in such a way that these becomes an essential part of themselves. Blenkinsop (1997:77) confirms this in a publication on

8 See the discussion of Nell (2008:6) on Rene Girard's concept of the cycle of violence.

9 See DA Louw en DJA Edwards (1998:296) in terms of the impact of selective memory on people.

Memories liberate the past 
Memory, Tradition, and the Construction of the Past in Ancient Israel when he says: "Memories are, however, communicable and, once communicated, can become part of the collective unconscious of a society, an ingredient, no doubt the central ingredient, of the tradition by which it understands itself and expresses its identity." Therefore an individual, group or nation with a good memory has a clear identity.

Durand (1993:290) questions whether it is possible to forget the pain of the past, even if we live in a time of technological progress where the emphasis is on marginalising pain while in tandem with the social-political society which continues to pressurise us toward forgetting the past and moving on. This is done subtly by propagating a worldview where there is no place for pain and suffering because the emphasis is on prosperity and success. Failure is therefore never an option. ${ }^{10}$

When confronted with change and transformation people may tend to feel threatened by the possibility of past memories and associations resurfacing. Within a reconstruction process it is inevitable that there will be a correlation between the pain of the past and what people experience in the present. Durand (1993:291) indicates that it is easier for privileged groups to forget than for the suppressed or marginalised groups. On the other hand he also indicates that it is always a challenge for the victims to remember the burden of past pain when it might prevent change in the present (Durand, 1993:291).

Individuals, groups and nations that choose not to remember the past; whether it is accidental, deliberate or ideological, continue to struggle with their identity, especially when their past is filled with traumatic events and violence. Forgetting the traumatic past can be a way of denying the past. This is echoed by Olivera (1996:55): "Forgetting may be a necessity, an imperative that acts as a defence mechanism, for someone who has had a traumatic experience, for instance. Hence a "sleep cure" as a form of therapy or relief." It is therefore understandable that perpetrators and victims may choose to forget the pain of the past because it is just too difficult to face it and it may also threaten their identity as an individual, group or nation.

\section{MEMORY REQUIRES RESPONSIBILITY}

For healing to take place, both the victim and the perpetrator need to take responsibility for dealing with their past constructively. This will imply that both victim and perpetrator need to work actively towards stopping the cycle of being a victim today and a perpetrator tomorrow. Gutiérrez (1979:80) warns against what he calls 'historical amnesia': "For this memory of past battles is not a matter of reassuring nostalgia and pleasant reveries. It is a subversive memory, and it lends force and sustenance to our positions, refuses to compromise or equivocate, learns from failures, and knows (by experience) that it has the capability of overcoming every obstacle, even repression itself." It is therefore evident that the victim and the perpetrator should not allow historical amnesia to derail their responsibility to stop the cycle.

Responsibility further implies creating time and space to remember the past actively. In this sense Vosloo (2010:2) reminds that at the speed people live their lives in the present, they could indeed block processes of remembering so that the past becomes a blur, with the result that an honest and healing interaction with the past becomes difficult or even impossible. This is emphasised by the Croatian theologian, Miroslav Volf (2006:39), in his book, The End of

10 Durand (1993:292) refers in this regard to the areas of the-medical science and technology. The core of his argument is that the rapid development within medical technology creates the impression that people need to move as fast as they can toward the future and therefore need to forget the past and the present. He warns us that if people follow this way a new theodicy needs to be born. This is frightening because it will be all secularized. 
Memory: Remembering Rightly in a Violent World: "As the media nail us to the narrow strip of the extended present, and as the new replaces the old with breathtaking speed, the past seems like a landscape viewed from a fast-moving train - a blur that quickly fades to black".

Responsibility further implies taking the past seriously. Klaus Barbie, one of the Nazi-leaders said during his trial, more than 40 years after the Nazi regime had ended, that he believes one must never forget, because forgetting would be accepting that things can happen again. In this sense forgetting can imply that considering what happened was of little importance. It is therefore about acknowledging and accepting the past, and not about trying to minimise the injustices of the past or to trying to justify them in any way. Remembering can therefore never be just remembering: it is essentially al so about taking responsibility for past memories. Petersen (1996:57) adds to this when he states that it is impossible to accept the offer of forgiveness and reconciliation without any reciprocal owning of responsibility and action. Victims and perpetrators are responsible for their deeds and actions because they are part of history and they had to make choices to survive. These choices determines to some extent the way they live. Sometimes they tend to forget the choices they made and try to hide behind the excuse that 'they did not know'. By doing this, people shift their responsibility directly onto others.

Victims and perpetrators therefore need to take responsibility for their deeds by taking responsibility for their fellow human beings. Ackermann's (1996:50) understanding of accountability helps us in this regard: "Accountability is, however, not limited to being faithful only to the values and vision of the community from which one comes, but is ultimately tested in the reality of the well-being of all. I am accountable for your welfare, and yours, in the sense that I may not act in any way which places it in jeopardy." The advantage of taking responsibility is that it helps victims and perpetrators to enter a world which they have forgotten, never experienced before or have to revisit again. They need one another to move into this world. This is only possible when victims and perpetrators are exposed to each other's narratives. "Indeed, when I understand truth as story, I am more likely to be open to other people's truth stories. As I listen to other stories, I am invited to move out of the subjectivity of my own story into another realm of thinking and acting. The same is true for others when I tell my story... Indeed it is only when we refuse to listen to another's story that our own story becomes ideological, that is, a closed system incapable of hearing the truth (Cone, 1975:103 -104)." This experience changes them because it makes them aware of the life of others. It also reforms their ability to care for others and build meaningful relationships with others ${ }^{11}$. This paves the way toward taking responsibility for the choices and actions they have followed. "We are accountable for our lack of awareness. Equally we are capable of waking up. Being awake means that we will hear the truth, accept accountability and dedicate ourselves to reconciliation" (Ackermann 1996:52).

Responsibility further implies communicating the content, emotions and impact of the pain suffered. It is about making the memories of the past public. It is not only about telling the positive stories but it is essential to share the stories that divide, hurt and almost destroy victims and perpetrators. The reality is that if they fail to do so "these differences have the capability of destroying the future" (Villa-Vicencio, 1995:105). These stories need to be told, by both victims and perpetrators, in order to take responsibility, bring change and experience healing. "Hearing these stories has changed many people's perceptions. It unmasked the evil character of an imposed ideology and its lack of sound theological norms and values. The stories revealed the invisible wounds and scars of the South African nation" (Louw, 1999:10). Botman (1996:37) describes the power of these stories by stating that: "In South Africa we see people coming to life in and through their stories. We see people rebuilding their family names word by word as

11 See Smit (1995:3) as he confirms the importance of remembering and confessing the past "No reconciliation with God, with those closest to you, with others, or with yourself is possible". 
they narrate their painful histories. We are confronted by people returning from the dead in the stories that have been nurtured in the hearts of many people, victims and perpetrators. To the one, a story of love; to the other, a story of hatred."

By taking responsibility for the past the perpetrator and the victim create a new identity, a shared identity or as Holtschneider (2001:16) describes it, a 'collective memory'.

\section{MEMORY AND SHARING LEADS TO LIBERATION}

Storytelling is in essence about remembering what happened in the past and considering the impact it has on the present and the future. When victims and perpetrators remember and share their painful stories ${ }^{12}$ in a safe space, it helps them to start dealing with the past but also to interpret the past in order to create a better future ${ }^{13}$. These safe spaces form communities of memory where victims and perpetrators learn to speak the truth again. The well-known theologian Niebuhr (1941:30), more than sixty years ago emphasised the importance of sharing our narrative in public so that it can lead to healing from our past.. According to him, narratives have the following outcomes:

\section{Make the past understandable}

According to Niebuhr (1941:30) the past must be understood: "There is no part of that past that can be ignored or regarded as beyond possibility of redemption from meaninglessness and it is the ability of the revelation to save all the past from senselessness that is one of the marks of its revelatory character." Every person, family, community and nation has a story to tell about their past. There are no good or bad stories, and no spectacular or basic stories. "Every person has a story to tell, something to say to themselves, their children, and to the world, about how they think and live, as they determine their reason for being...When people can no longer listen to the other people's stories, they become enclosed within their own social context... And then they feel they must destroy other people's stories (James Cone, 1975:102)."

\section{Forces us to remember what we have forgotten}

Niebuhr (1941:30-31) explains the importance of remembering: "By reasoning on the basis of revelation, the heart not only understands what it remembers but is enabled and driven to remember what it had forgotten. When we use insufficient and evil images of the personal or social self, we drop out of our consciousness or suppress those memories which do not fit in with the picture of the self we cherish. We bury our follies and our transgressions of our own law, our departures from our own ideal, in the depths of our unconsciousness. We also forget much that seems to us trivial, since it does not make sense when interpreted by means of the idolatrous image... We do not destroy this past of ours; it is indestructible. We carry it with us; its record is written deep into our lives. We only refuse to acknowledge it as our true past and try to make it an alien thing - something that did not happen to our real selves. So our national histories do not recall to the consciousness of citizens, the crimes and absurdities of past social conduct, as our written and unwritten autobiographies fail to mention our shame. But this unremembered past endures ... When we live and act in accordance with our inward social constitution in which there are class and race divisions, prejudices, assumptions about the things we can and cannot do, we are constrained by the unconscious past. Our buried past is mighty; the ghosts of our fathers and of the selves that we have been haunt our days and nights though we refuse to acknowledge their presence."

12 See Schreiter (2004:44-46).

13 See Baumgartner (1990:112). 


\section{Make it possible to adopt and own the stories of others as our own}

According to Niebuhr (1941:35) this forms the most essential part of the process: "When men enter into a new community they not only share the present life of their new companions, but also adopt as they own the past history of their fellows". If a nation lacks common memory by which people do not share in the same past, there can be no real community. The one side needs knowledge of the contemporary life of the other side of the community. Community can only be formed where common memory is created.

The power and meaning of storytelling is the first element toward the creation of a common memory by which perpetrators and victims gain insight into each other's pain. The value of storytelling resides in its ability to empower perpetrators and victims to change their behaviour and to create new paradigms for a meaningful life. Louw (1999:10) refers to the transforming power of the narrative when he quotes the psychologist K. Patrick in this regard: "A story provides transport; it reveals moral codes and sets normative standards; it reveals what could be called self-recognition; it promotes character changes in terms of transformation rather than in terms of development; great stories have powerful images, images striking enough to be lodged in memory; they allow us to identify with morals of virtue and courage; stories personalize moral issues, removing them from the level of abstraction to the level of immediacy; they encourage a narrative understanding of the self." When someone is therefore ready to tell their story, they are ready to be formed by the stories of others. Within these shared experiences perpetrators and victims are able to identify, interpret and understand each other's narratives.

However, the power and meaning of storytelling is not limited to an individual process but can also take place collectively. Stories have the ability to create a corporate and a collective identity. Within the context of this article the challenge is to connect God's narrative with the human narrative. It is about linking my story, with the story of Jesus and then with the (collective) South African story. In this way God's narrative can help a victim and a perpetrator as well as a community or a nation to reconstruct the narratives of the past and the present in such a way that they can lay the basis for transformation toward a meaningful life. God reforms the individual, group and the nation through the work of the Holy Spirit.

\section{CONCLUSION}

It is clear from a psychological point of view that the trauma of the past needs to be remembered, to ensure that it is not suppressed, denied nor forgotten by those involved. When remembering is neglected, healing will not be possible. Remembrance also has a biblical and theological meaning that forms the basis for healing and reconciliation. In this regard Scripture refers to liberated or redemptive memory. This implies that it deals with life from death, light from darkness, good from bad and hope from despair.

Remembrance and memory are key elements of the healing and reconciliation process for victims and perpetrators. Because of their different backgrounds and experience of the traumatic past and the way these formed their own identities, it is essential that they remember the past and share it in public with each other. As the remembrance and storytelling process develops, it will pave the way for forming a communal identity. For this to develop it is important to understand that remembrance is not only an individual process but also a collective process. In this way the value of storytelling will be the sharing of the narratives (individually and collectively) and this will lead to liberation from the past, finding meaning in the present and living in hope for the future. 


\section{BIBLIOGRAPHY}

Ackermann, DM 1996. On Hearing and Lamenting: Faith and Truth Telling, in Botman, HR\& Petersen, RM (eds), To Remember and to Heal, 47-56. Wynberg: Human en Rousseau.

Baumgartner, I 1990. Pastor - Psychologie: Einführung in die Praxis heilender Seelsorge. Düsseldorf: Patmos Verlang.

Blenkinsopp, J 1997. Memory, Tradition, and the construction of the past in ancient Israel, in Biblical Theology Bulletin, Vol. 27, 76-82.

Botman, HR 1996. Narrative Challenges in a Situation of Transition, in Botman, HR \& Petersen, RM (eds), To Remember and to Heal, 47-56. Wynberg: Human en Rousseau.

Cone, J 1975. God and the oppressed. New York: Seabury.

Durand, JJF 1993. In bewuste herinnering, in Intellektueel in konteks, 289-304. Essays for Hennie Rossouw. Pretoria: RGN.

Gutiérrez, G 1983. The Power of the Poor in History. New York: SCM Press.

Holtschneider, KH 2001. German Protestants Remember the Holocaust. London: Lit Verlag.

Huber, W 1987. Versöhnung beginnt, wo Verdrängung endet. Frunkfurter Rundschau Vol. 27. Und 29.6.

Jordaan, W 2008. “Onthou om te onthou / vergeet om te vergeet”, in Botman, HR \& Petersen, R M (eds), To Remember and to Heal, 47-56. Wynberg: Human en Rousseau.

Louw, DA\& Edwards, DJA 1998. Sielkunde. Johannesburg: Heinemann.

Louw, DJ 1999. Pastoraat as vertolking: Metaforiese teologie binne die konteks van 'n pastorale hermeneutiek, in Hervormde Teologiese Studies, Vol. 55 (2 \& 3), 334-359.

Metz,JB 1980. Faith in History and Society: Toward a Fundamental Practical Theology. New York: Seabury. Nell, I 2008. The tears of Xenophobia: Preaching and violence from a South African perspective. Unpublished article.

Nwoye, A 2005. Memory healing processes and community intervention in Grief work in Africa, in ANZJFT, Vol. 26, 3,147-154.

Nwoye, A 2008. Memory and narrative healing processes in HIV counselling: A view from Africa, in Contemp fam ther, 30,15-30.

Olivera, A 1996. Forgetting and Remembering, in Harper, C (ed) Impunity: An ethical perspective, 55-60. Geneva: WCC. .

Santer, M 1988. The Reconciliation of Memories, in Falconer, AD, Reconciling Memories, 128-134. Dublin: Columbia.

Schreiter, RJ 2004. The ministry of reconciliation. New York: Orbis.

Petersen, RM 1996. The politics of Grace and the Truth and Reconciliation Commission, in Botman, HR\& Petersen, RM To Remember and to Heal, 57-64. Cape Town: Human \&Rousseau

Ricoeur, P 2004. Memory, History, Forgetting. Chicago: The University of Chicago Press.

Smit, DJ 1995. The Truth and Reconciliation Commission - Tentative Religious and Theological Perspectives, in Journal of Theology for Southern Africa, 3-16.

Veldsman, D 2008. Herinneringe: Waarvan ons aanmekaar gesit is en waarvan ons leef, in Jordaan, W, $\mathrm{R}$ van Vuuren, D Veldsman, C Vos \& C Thesnaar Die genesing van die herinneringe, 24-34. Protea Boekhuis: Pretoria

Villa-Vicencio, C 1995. Telling One Another Stories: Towards a Theology of Reconciliation, in Villa-Vicencio, C \& Niehaus, C (eds) Many Cultures, One Nation. Cape Town: Human \& Rousseau.

Volf, M 2006. The End of Memory: Remembering Rightly in a Violent World. Grand Rapids: Eerdmans Vosloo, R 2009. Memory, tradition, theology: En route to a responsible historical hermeneutics.

Presentation at the Theological Day, Faculty of Theology, Stellenbosch University 2 February 2009.

\section{KEY WORDS}

Memory

Reconciliation

Victim

Perpetrator

identity 


\section{TREFWOORDE}

Herinnering

Versoening

Slagoffer

Oortreder

Identiteit

KONTAKBESONDERHEDE:

Dr Christo Thesnaar

Fakulteit Teologie

Universiteit van Stellenbosch

Privaatsak X1

7602 MATIELAND

E-posadres: cht@sun.ac.za

Sel: 0845734322 